\title{
LAONICE BRANCHIATA, A NEW SPECIES OF SPIONIDAE (ANNELIDA; POLYCHAETA) FROM THE SOUTHEASTERN BRAZILIAN COAST
}

\author{
Edmundo Ferraz Nonato * \\ Germán Armando Bolívar ** \\ Paulo da Cunha Lana ***
}

\begin{abstract}
Laonice branchiata, a new spionid polychaete, is described based on material collected in shallow waters of estuarine and shelf environments off the States of Paraná, São Paulo and Rio de Janeiro (SE Brazil).

Key-words: Polychaetes; taxonomy; Spionidae; Laonice branchiata

\section{RESUMO}

(Laonice branchiata, uma nova espécie de Spionidae da costa sudeste brasileira). Laonice branchiata, uma nova espécie de poliqueta da família Spionidae, é descrita a partir de material coletado em ambientes estuarinos e de plataforma ao longo dos estados do Paraná, São Paulo e Rio de Janeiro (costa sudeste do Brasil).

Palavras chave: Poliquetas; taxonomia; Spionidae; Laonice branchiata

\section{INTRODUCTION}

An account of the occurrence and distribution patterns of Spionidae from South America was recently given by BLAKE (1983). Most of his descriptions and comments were concerned

\footnotetext{
* Instituto Oceanográfico, Universidade de São Paulo, 05508 Cidade Universitária, São Paulo

** Curso de Pós-Graduação em Zoologia, Universidade Federal do Paraná, Curitiba

*** Centro de Biologia Marinha, Universidade Federal do Paraná, 83.200 Pontal do Sul, Paraná.
} 
with Magellanic and Argentinean species. The spionid fauna from Brazilian waters remains poorly studied. About fifteen species, mainly from the southeast coast, are presently known; most of them were described or recorded in unpublished thesis (NONATO, 1981; BOLIVAR, 1986). During a survey of the polychaete fauna from the Grande Island and adjacent waters (Rio de Janeiro), one of the authors ( $E$. N.) found a new form of Laonice, that was informally described in one of the cited thesis (NONATO, 1981); it was later rediscovered both in the estuarine environment of the Bay of Paranaguá $\left(25^{\circ} 30^{\prime} \mathrm{S}-48^{\circ} 20^{\prime} \mathrm{W}\right)$ and in shallow shelf bottoms off the Paraná coast. This is a very common species in the inner continental shelf all along the Brazilian southeast coast. A formal description of it is presented below in order to avoid the usage of a manuscript name in further ecological or systematics studies. Due to its adequacy and al ready established application in regional literature, the former name branchiata is preserved.

The holotype is deposited at the Centro de Biologia Marinha, Universidade Federal do Paraná, Pontal do Sul, Paraná (Type collection, MCBM-BPO-52). Part of the studied material is at the Benthos Department, Instituto Oceanográfico, Universidade de São Paulo. Paratypes were sent to the National Museum of Natural History (Smithsonian Institution, USNM 100 451).

Family Spionidae Grube, 1850

Genus Laonice Malmgren, 1857

Laonice branchiata, new species

Material examined - Atlantic Ocean off Paraná coast (SE Brazil): St. 6077, Op. Sueste I, R/V "Almirante Saldanha", $26^{\circ} 44^{\prime} \mathrm{S}, 48^{\circ} 25^{\prime} \mathrm{W}, 1$ August 1982,37 meters, fine sand and mud (2 paratypes, MCBM-BPO-53). St. 6140, Op. Sueste I, $24^{\circ} 06^{\prime} S$, $46^{\circ} 10^{\prime} \mathrm{W}, 21$ August 1982, 33 meters, sand and mud (2 paratypes, MCBM-BPO-54). Bay of Paranaguá: St. A-2, Paranaguá Harbour, 7 November 1981, 15 meters, sand and mud (HOLOTYPE, MCBMBPO-52). São Paulo and Rio de Janeiro States: about a hundred specimens from shelf depths near Grande and Anchieta Islands and inlets all along the coast of São Paulo, from Ubatuba in the north to Cananéia in the south (Benthos Department, Instituto Oceanográfico, Universidade de São Paulo). 
Diagnosis - Anterior region of the body, formed by prostomium and peristomial wings, semi-elliptical in form, without frontal horns. Prostomium extendig posteriorly to setigers 9-10 as a narrow keel, with occipital antenna. Branchiae from setiger 2, provided with accessory auricular lobes with 6-7 vascularized loops. Bidentate neuropodial hooks in posterior setigers, followed by 1-2 genital setae. Pygidium with 12 anal cirri of similar sizes.

Description - The holotype is a complete specimen with 130 setigers that is $54 \mathrm{~mm}$ long and $1,5 \mathrm{~mm}$ wide, without parapodia Length of complete paratypes is up to $65 \mathrm{~mm}$, with 200 setigers. Specimens are pale yellow to whitish in alcohol, lacking evident color patterns; dorsal lamellae may be conspicuosly pigmented.

The anterior region of the body, formed by the prostomium and peristomial wings, is semi-elliptical, lacking frontal horns or lateral expansions (Fig. 1). The prostomium extends posteriorly as a median keel or caruncle for 9-10 setigers. The occipital tentacle or antenna is well developed and inserted at the level of setiger 1 . There are two pairs of brown to reddish eyes, the posterior ones elongate and recurved and much larger. The anterior eyes, evident as a rule, are represented by diffuse pigment spots. Palpi are short and thick, easily deciduous in preserved specimens.

Lanceolate branchiae are first present from setiger 2, basally free from the notopodial lamellae (Fig. 2) and continuing posteriorly to setigers $40-41$ (unusually to a more anterior one). Branchiae are typically provided with an antero-median crest, basally enlarged to form an auricular lobe with 6-7 vascularized loops (Figs. 2 and 3). These accessory loops are little developed in the first setigers, increase in size in median setigers and decrease again in the posterior region; they are present in all examined specimens and do not seem to be related to size of individuals or maturation phase.

Notopodial lamellae are foliaceous and well developed, larger in median setigers. Neuropodial lamellae are auriculate and shorter than the notopodial ones (with the exception of setiger 1). Both dorsal and ventral lamellae are rounded and smaller in posterior setigers (Fig. 4).

Anterior noto - and neurosetae are all capillary, similar in 
form and arrangement. There can be shorter or longer capillaries, with granulated shaft and narrow sheaths (Fig. 5). Neuropodial hooded hooks are first present from setigers 27-37 (from the last branchiated or first post-branchiated setigers). Hooks are clearly bidentate, numbering 6-10 per fascicle (Fig. 6). There are 1-2 genital or inferior sabre setae, strongly curved and granulated.

Double dorsal folds are present from setiger 2, better seen from setiger 4 and evident up to setigers 66-68. Genital pouches begin between setigers 4 and 5 , continuing posteriorly to the end of the body.

There are 10 lateral and 2 ventral anal cirri, all of similar size and inserted in a bulbous base (Fig. 7).

Discussion - FOSTER (1971) did not accept the usage of distribution of genital pouches for distinguishing species of Laonice and lumped all forms known up until then into Laonice cirrata. This procedure was questioned by HARTMAN (1978), BLAKE \& KUDENOV (1978) and BLAKE (1983), who revalidated previously synonimized forms or described new taxa, based in characteristics other than the first occurrence of genital pouches. At least three Laonice species are presently known from shelf, slope or abyssal depths off the Brazilian coast: Laonice cirrata, Laonice antarcticae and Laonice branchiata (HARTMAN, 1965; ORENSANZ \& GIANUCA, 1974; NONATO, 1981; BLAKE, 1983; BOLIVAR, 1986). Laonice branchiata differs from all the other described species of the genus in having presetal vascularized lobes at the base of anterior branchiae; these lobes probably function as true accessory branchiae. The semi-elliptical shape of the anterior region of the body is sharply different from those of Laonice antarcticae and Laonice cirrata; this shape is constant in all examined specimens.

Etymology - The specific name refers to the presence of a vascularized auricular lobe at the base of the branchiae.

Distribution - Laonice branchiata is known from several localities off the coast of southeastern Brazil and from estuaries and inlets along the coast of Rio de Janeiro, São Paulo and Paraná States. 


\section{REFERENCES}

BLAKE, J.A. 1983. Polychaetes of the family Spionidae from South America, Antarctica and adjacent seas and islands. Ant. Res. Ser., 39(3): 205-288.

BLAKE, J.A. \& J.D. KUDENOV. 1978. The Spionidae (Polychaeta) from southeastern Australia and adjacent areas with a revision of the genera Mem. Nat. Mus. Vic., 39:171-280.

BOLIVAR, G. 1986. Padrões de distribuição de Spionidae e Magelonidae (Annelida; Polychaeta) do litoral do estado do Paraná. Tese de Mestrado, Universidade Federal do Paraná, $115 \mathrm{p}$.

FOSTER, N. 1971. Spionidae (Polychaeta) of the Gulf of Mexico and the Caribbean Sea. Studies on the Fauna of Curaçao and on the other Caribbean Islands, 36:1-183.

HARTMAN, O. 1965. Deep water benthic polychaetous annelids off New England to Bermuda and other North Atlantic areas. Occ. Pap. All. Hanc. Fdn, 28:1-378.

HARTMAN, O. 1978. Polychaeta from the Weddell Sea Quadrant, Antarctica. Ant. Res. Ser., 26(4):124-123.

NONATO, E.F. 1981. Contribuição ao conhecimento dos anelídeos poliquetos bentônicos da plataforma continental brasileira, entre Cabo Frio e Arroio Chuí. Tese de Livre Docência, Instituto Oceanográfico, Universidade de São Paulo, 246 p.

ORENSANZ, J.M. \& N.M. GIANUCA. 1974. Contribuição ao conhecimento dos anelídeos poliquetas do Rio Grande do Sul, Brasil. I. Lista sistemá tica preliminar e descrição de três novas espécies. Comun. Mus. C: PUC-RGS, 4:1-37. 

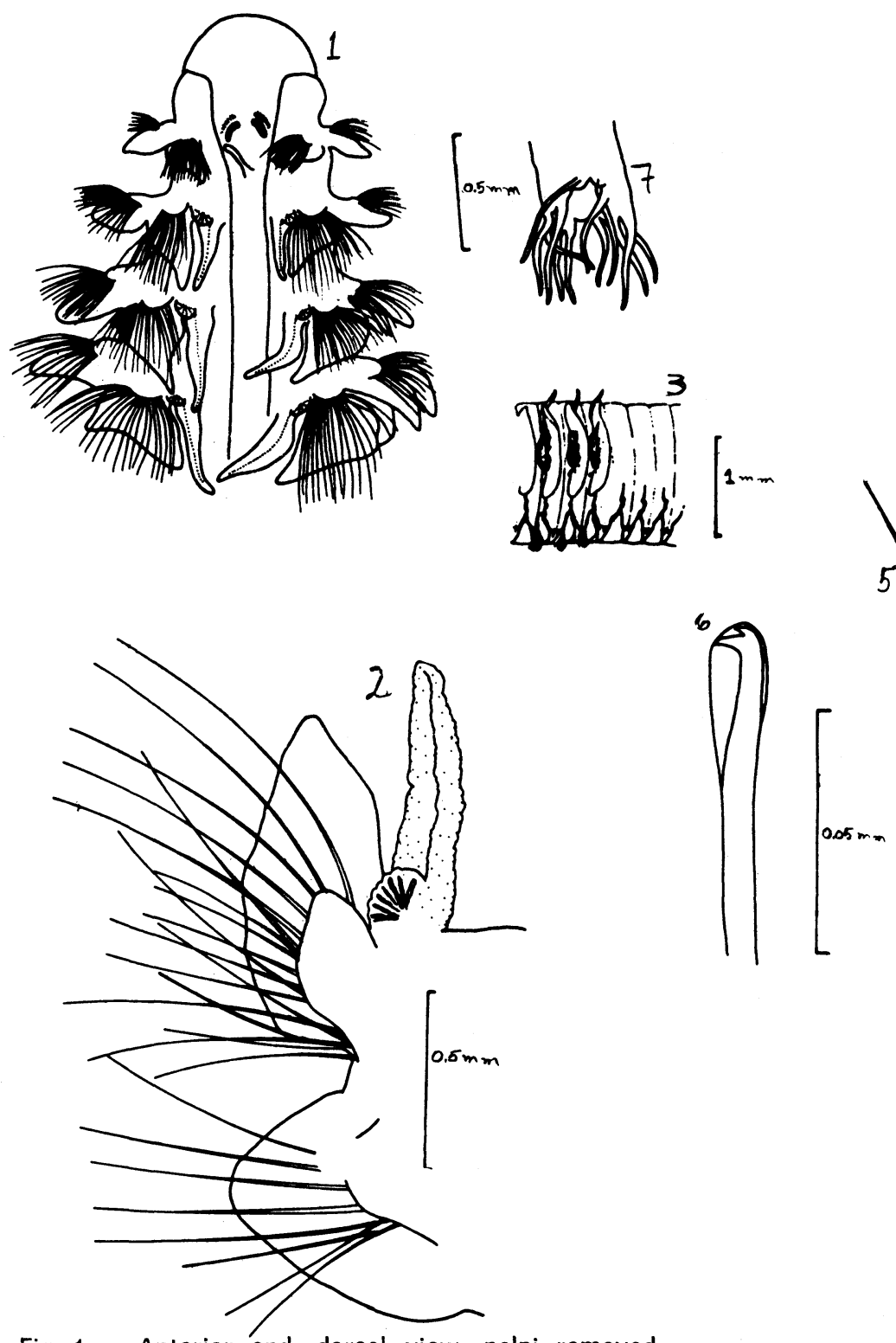

Fig. 1 - Anterior end, dorsal view, palpi removed

Fig. 2 - Right parapodium, setiger 7

Fig. 3 - Antero-median region of the body, lateral view

Fig. 5 - Notoseta, anterior parapodium

Fig. 6 - Bidentate neuropodial hook, setiger 36

Fig. 7 - Pygidium, ventral view 


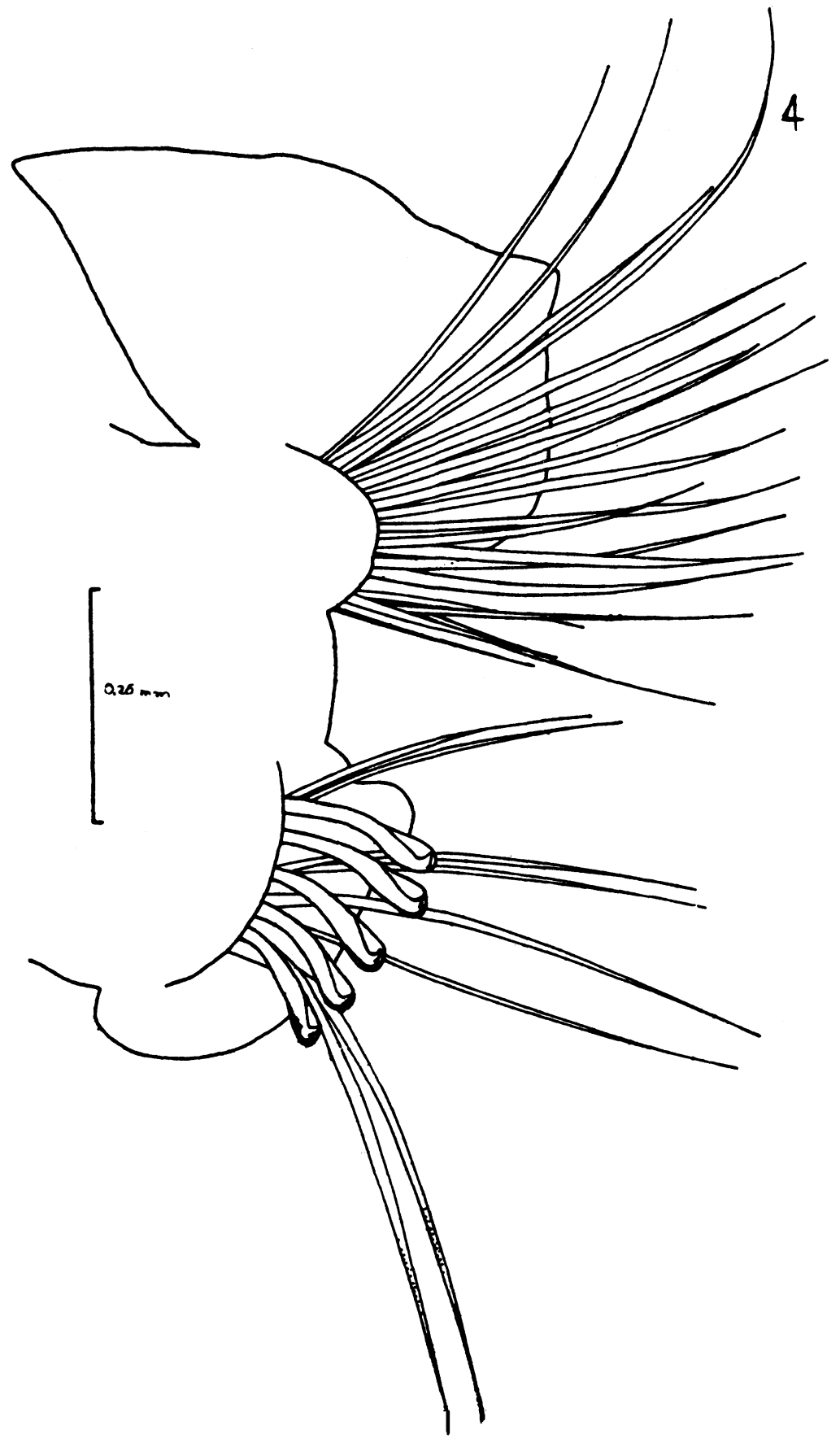

Fig. 4 - Left parapodium, setiger 53 